\title{
Lead transfer in the soil-root-plant system in a highly contaminated Andean area
}

\author{
Jorge I Castro-Bedriñana ${ }^{\text {Corresp., } 1}{ }^{1}$, Doris M Chirinos-Peinado ${ }^{2}$, Edgar García-Olarte $^{3}$, Rolando Quispe-Ramos ${ }^{3}$ \\ ${ }^{1}$ Specialized Research Institute of the Faculty of Zootechnics, Universidad Nacional del Centro del Perú, Huancayo, Junín, Perú \\ 2 Nutritional Food Safety Research Center, Universidad Nacional del Centro del Perú, Huancayo, Junín, Perú \\ 3 Faculty of Zootechnics, Universidad Nacional del Centro del Perú, Huancayo, Huancayo, Perú \\ Corresponding Author: Jorge I Castro-Bedriñana \\ Email address: jcastro@uncp.edu.pe
}

Lead $(\mathrm{Pb})$ is highly toxic heavy metal that is detrimental to the food system. There are large mining and metallurgical companies in the central highlands of Peru that have been active for almost a century and contribute to air, water, and soil pollution, affecting food quality and causing damage to the environment and human health. Our study, conducted in 2018, assessed the content and transfer of lead in the soil-root-plant system in the high Andean grasslands in a geographical area near the metallurgical complex of La Oroya. Lead levels were measured in 120 samples of top soil $(0-20 \mathrm{~cm})$, roots, and grass shoots by flame atomic absorption spectroscopy. No significant differences were found between the soil $\mathrm{pH}$, organic matter content, and lead among the samples evaluated $(P>0.05)$. Mean $\mathrm{Pb}$ concentrations decreased in the order of soil $>$ root $>$ shoot $(P<0.01)(212.36 \pm$ $38.40,154.65 \pm 52.85$ and $19.71 \pm 2.81 \mathrm{mg} / \mathrm{kg}$, respectively). The soil-to-root $\mathrm{Pb}$ bioconcentration factor, root-to-shoot translocation factor, and soil-to-shoot bioaccumulation factor values were $0.74 \pm 0.26,0.14 \pm 0.06$ and $0.10 \pm 0.03$, respectively. Lead in the soil was 3.03 times higher than the maximum limit for agricultural soil, and was 1.97 times higher than the value limit for fodder. Our findings are important and show that soils and pasture in this geographical area have high $\mathrm{Pb}$ levels due to metallurgical emissions that have been occurring since 1922. Such pollution negatively impacts health and the socio-economic status of the exposed populations. 


\title{
Lead transfer in the soil-root-plant system in a high contaminated Andean area
}

\author{
Jorge Castro-Bedriñana $^{1 *}$, Doris Chirinos-Peinado ${ }^{2}$, Edgar García-Olarte ${ }^{3}$, Rolando Quispe- \\ Ramos $^{3}$ \\ ${ }^{1}$ Specialized Research Institute of the Faculty of Zootechnics, Universidad Nacional del Centro \\ del Perú, Huancayo, Junín, Perú \\ ${ }^{2}$ Nutritional Food Safety Research Center, Universidad Nacional del Centro del Perú, Huancayo, \\ Junín, Perú \\ ${ }^{3}$ Faculty of Zootechnics, Universidad Nacional del Centro del Perú, Huancayo, Junín, Perú \\ *Corresponding author: Jorge Castro-Bedriñana \\ Email address: jcastro@uncp.edu.pe
}

\section{Abstract}

Soil lead is not an essential factor in agricultural production; on the contrary, it is a heavy metal that is highly toxic to the nutritional food system. In the central highlands of Peru, there are large companies have been engaged in mining and metallurgical activities for almost a century and pollute the air, water and soil, affecting the quality of food and causing damage to the environment and human health. In this context, the study carried out in 2018 assesses the content and transfer of lead in the soil-root-plant system in the high Andean grasslands in a geographical area near the metallurgical complex of La Oroya. Lead levels were measured in 120 samples of top soil $(0-20 \mathrm{~cm})$, roots and grass shoots by flame atomic absorption spectroscopy. No significant differences were found between soil $\mathrm{pH}$, organic matter content and lead among the samples evaluated $(P>0.05)$. Mean $\mathrm{Pb}$ concentrations decreased in the order soil $>$ root $>$ shoot $(P<0.01)$, being $212.36 \pm 38.40,154.65 \pm 52.85$ and $19.71 \pm 2.81 \mathrm{mg} / \mathrm{kg}$, respectively. The soil to root $\mathrm{Pb}$ bioconcentration factor, root to shoot translocation factor and soil to shoot bioaccumulation factor values were $0.74 \pm 0.26,0.14 \pm 0.06$ and $0.10 \pm 0.03$. Lead in soil was 3.03 times higher than the maximum limit for agricultural soil and in fodder was 1.97 times higher than the limit value for fodder. Our findings are important and shocking and show that soils and pastures in this part of the world would have high $\mathrm{Pb}$ levels due to metallurgical emissions that have been occurring since 1922, negative impacts that could cause health and socio-economic problems in exposed populations.

Subjects: Environmental Contamination and Soil Science, Ecosystem Science, Environmental impacts

\section{Introduction}

Lead $(\mathrm{Pb})$ is highly toxic to living organisms; it is naturally present in the earth's crust in harmless concentrations, usually between 15-40 mg / kg (Fahr et al., 2013; Amari et al., 2017). 
According to the European REACH regulation and the Agency for Toxic Substances and Disease Registry, $\mathrm{Pb}$ is the second most harmful contaminant to humans after arsenic (ATSDR, 2007; Pourrut et al., 2011).

$\mathrm{Pb}$ is widely used in industry (Wuana \& Okieimen, 2011) and its metallurgical process emits fine particulate material that travels many kilometers through the air (Martin et al, 2017) depositing in water, soil and when it exceeds certain limits it geoaccumulates, bioaccumulates and biomagnifies (Lokeshwari \& Chandrappa, 2006), and can reach toxic levels with serious consequences for ecosystems (Alloway, 2013; Kong, 2014).

Anthropogenic $\mathrm{Pb}$ released into the atmosphere is deposited and accumulated in the upper soil layer and, due to its long biological half-life and high bioaccumulation potential, is absorbed by plant roots (Nascimento et al., 2014; Hou et al, 2014), generating Pb-laden foods that are harmful to human health (Li et al., 2005; Li et al., 2017; Castro, Chirinos \& Rios, 2016; Martin et al., 2017), especially for infants and children (Chirinos-Peinado \& Castro-Bedriñana, 2020).

Soil quality plays an important role in food safety by determining the possible composition of forage at the early levels of the food chain (Tóth et al., 2016); so, analysis of the top of the soil (typically the top $0-20 \mathrm{~cm}$ ) is valuable in assessing heavy metal contamination in grasslands (Martin et al., 2017).

Soil contamination and its potential impact on human health has not been extensively studied in Peru, especially in the high Andean areas where mining and metallurgical activities are carried out in addition to livestock activities (Chang Kee et al., 2018).

The La Oroya polymetallic mining-metallurgical complex, in operation since 1922, generates emissions and acid fumes that exceed international standards and contaminate the surrounding ecosystems (Álvarez-Berríos et al., 2016), so much so that La Oroya is now the fifth most contaminated place on the planet (Blacksmith Institute, 2007) and in these almost 100 years the soils and vegetation of central Peru have been contaminated by heavy metals and toxic substances (Álvarez-Berríos et al., 2016; USDA, 2017).

A recent study shows that milk produced in an area close to the metallurgical industry has quantities of $\mathrm{Pb}$ and $\mathrm{Cd}$ above the maximum permitted levels (Chirinos-Peinado and CastroBedriñana, 2020), which makes soil quality an issue of economic and social importance (Kong, 2014) not only for Peru but for the world.

The threshold of $\mathrm{Pb}$ content in agricultural soils and forages have wide variations (Chen et al., 2018). Bulgaria, Denmark, Russia, Thailand, Norway, Finland and the Czech Republic set the lowest values $(40,40,55,55,60,60$ and $60 \mathrm{mg} / \mathrm{kg})$, while Switzerland, Belgium, the Republic of Korea and the Netherlands set the highest values $(1000,700,600$ and $530 \mathrm{mg} / \mathrm{kg}$ ).

In Peru, the Ministry of the Environment establishes an Environmental Quality Standard for agricultural soils of $70 \mathrm{mg} / \mathrm{kg}$ (MINAM, 2017).

Many studies on heavy metal contamination have been generated in controlled studies with pre-set amounts of samples (Adamse, Van der Fels-Klerx, 2017); therefore, a strength of this ecological study is its in-situ design over time. 
Information on $\mathrm{Pb}$ contamination in the soil-root-plant system in an area affected by metallurgical emissions in the Andean region generates scientific evidence for monitoring $\mathrm{Pb}$ contamination in the soil and its transfer to the food chain base.

There are reports that the absorption and bioaccumulation of heavy metals in plants depends, among other factors, on the plant species (Sharma and Dubey, 2005) and seasonal variations (Bidar et al, 2009; Yabanli, Yozukmaz and Sel, 2014), this study has determined the concentrations and transference of $\mathrm{Pb}$ in the soil-root-blossom system of natural and cultivated pastures in samples collected during the rainy and dry seasons, well defined seasons in the central Andes, in an area of cattle, sheep and camelid farming in South America, located $20 \mathrm{~km}$ from the largest polymetallic metallurgical complex in this region of the world.

The $\mathrm{Pb}$ content of the soil was compared with the Peruvian standard of the Ministry of Environment and due to the existence of a national standard, the $\mathrm{Pb}$ of the forage was compared with an international standard.

\section{Materials and methods Study approval}

The study was approved by the Evaluation Committee of the Research General Institute of the Universidad Nacional del Centro del Perú, study which is part of a larger project (Project number: 1565-R-2917-UNCP). Sampling of soil and grasslands was approved by the President of the Peasant Community "Purísima Concepción de Paccha", Yauli, La Oroya.

\section{Description of the study site}

The research was carried out in the pastures of the Paccha Peasant Community, located in the central Andes of Peru, department of Junin, province of Yauli (8 724632.8 N, 417610.7 E; 3750 $\mathrm{m}$ a.s.1., minimum and maximum temperature of -3.1 and $18.2^{\circ} \mathrm{C}$ ) that covers 16,564 ha of grassland, of which 13.73 ha are irrigated cultivated pastures.

The study site is located $20 \mathrm{~km}$ from the Polymetallic Metallurgical Complex of La Oroya, and is subject to particulate emissions that contaminate the ecosystem from the beginning of its activities. Figure 1 shows the location map and the distribution of the sampling points for cultivated and natural soils and pastures in April (post-rainfall) and September (post-dry) 2018.

This area was chosen because it is representative of the communities near La Oroya, and because of their agro-ecological conditions they are dedicated to raising cattle, sheep, and alpacas, having approximately 11 ha (hectares) of natural pastures composed mainly of Festuca dolichophylla, Bromus catharticus, Bromus lanatus, Nasella meyeniana, Calamagrostis heterophylla, Piptochaetium faetertonei, Nasella publiflora, Asiachnae pulvinata, Margaricarpus pinnatus, Oenothera multicaulis, Trifolium amabile and 6 ha of association Lolium perenne and Trifolium repens installed 15 years ago, characterized by a poor condition.

The quantification of $\mathrm{Pb}$ in the soil, roots and shoots was made by means of flame atomic absorption spectroscopy (FLAA) in the laboratory Baltic Control SAC, accredited by the National Institute of Quality of Peru. 
Figure 1. Partial map of La Oroya-Peru, research area (3900-4500 m asl). The image above

123

124

125

126

127

128

129

130

131

132

133

134

135

136

137

138

139

140

141

142

143

144

145

146

147

148

149

150

151

152

153

154

155

156

157

158

159 shows the path from the La Oroya mining-metallurgical complex. The lower image shows the study site and the distribution of sampling points $\left(1 \mathrm{~m}^{2} / \mathrm{sample}\right)$.

Contamination of the study area from emissions from the La Oroya mine/metallurgical complex is supported by the 2005 air dispersion modeling study of La Oroya, which highlights the relative importance that emissions from the main stack increase as the distance from the complex increases, while fugitive sources smaller than the main stack are responsible for most local impacts. The average wind speed is $5.76 \mathrm{~km} / \mathrm{h}$, with a predominantly northeast direction for different times of the year. The wind transports the fine particle material to surrounding communities, including Paccha (Ramirez and Corcuera, 2015) where it was conducted in the study.

\section{Sampling procedures}

Topsoil sampling (0-20 cm depth) was carried out at 20 points in the natural grassland area and 20 points in the cultivated grassland area (Figure 1), which were collected in April and September 2018. A total of 120 samples (soils: 40, roots: 40, shoots: 40) were collected using standardized sampling procedures (Tóth et al., 2016; Martin et al., 2017).

From the same sampling site soil and grasses of $1 \mathrm{~m}^{2}$ were sampled with a stainless-steel shovel, taking approximately $0.5 \mathrm{~kg}$ of soil from each sample point and the grasses present (Tóth, Jones, Montanarella, 2013). The grasses were divided into root and aerial parts (CastroBedriñana, Chirinos-Peinado, Peñaloza-Fernández, 2020), and all samples were placed in firstuse polyethylene bags with zippered closure to be taken to the laboratory.

\section{Laboratory analysis}

After natural drying for one day, the soil samples were crushed and screened with a $2 \mathrm{~mm}$ thick mesh to remove gravel, stone, and other materials (Martin et al., 2017). A portion of this sample was used to estimate the percentages of sand, silt and clay, the rest was pulverized and sieved in 100 mesh, obtaining a fine and homogeneous powder for analysis.

The organic matter in the soil was analyzed by the Walkley-Black method (Gessesse \& Khamzina, 2018) and the $\mathrm{pH}$ by the EPA 9045D of soil and residues (1:2.5 soil to water, w:w) using a model Orion $720 \mathrm{~A} \mathrm{pH} / \mathrm{mV} /$ temperature meter.

Roots and shoots were washed with abundant tap water to remove soil particles and rinsed three times with deionized water (Bidar et al., 2009), then dried at $70^{\circ} \mathrm{C}$ and finely ground (Ramsumair, Mlambo \& Lallo, 2014).

The samples were digested using the USEPA 3050B method (SW-846). Repeated additions were made of a mixture of concentrated nitric acid $\left(\mathrm{HNO}_{3}\right)$ and hydrogen peroxide $\left(\mathrm{H}_{2} \mathrm{O}_{2}\right)$ to one gram of dry sample. Hydrochloric acid $(\mathrm{HCl})$ was added to the initial digestate and the sample was refluxed. The digestate was diluted to a final volume of $100 \mathrm{ml}$ (USEPA, 1996). 
To quantify the $\mathrm{Pb}$ concentration of the different samples, the standard analysis procedure was followed (Tóth, Jones \& Montanarella, 2013), using a flame atomic absorption spectrophotometer AAS (NAMBEI AA320N), following the protocol of the Official Method 975.03 of the AOAC (AOAC, 1990; USEPA, 1996).

To ensure analytical precision, the blank method, duplicate samples, and the high- and lowrange control standard were used for every 15 samples analyzed. The Sigma-Aldrich $\mathrm{Pb} 986 \pm 4$ $\mathrm{mg} / \mathrm{kg}$ standard was used for the calibration curve. The detection limit of $\mathrm{Pb}$ was $0.2 \mathrm{mg} / \mathrm{kg}$.

The units of concentration of $\mathrm{Pb}$ were expressed in $\mathrm{mg} / \mathrm{kg}$. The Environmental Quality Standard of $70 \mathrm{mg} / \mathrm{kg}$ (MINAM, 2017) was used to evaluate the $\mathrm{Pb}$ concentration in soil and the maximum limit of $10 \mathrm{mg} / \mathrm{kg}$ dry matter for forage (Boularbah et al., 2006b; Kabata-Pendias \& Mukherjee, 2007).

\section{Lead transfer in the soil-root-plant system}

The bioaccumulation factor (BF) represents the potential capability of heavy metals' transmission from soil to the edible parts of vegetable (Hu et al., 2017). The equation used to estimate the $\mathrm{BF}$ of $\mathrm{Pb}$ from soil to shoot were the following:

$$
B F=[P b \text { Shoot }] /[P b \text { soil }]
$$

A plant's ability to accumulate metals from soils can be estimated using the bioconcentration factor (BCF) (Yoon et al., 2006), which is defined as the ratio of metal concentration in the roots to that in soil (Zou et al., 2011). A plant's ability to translocate metals from the roots to the shoots is estimated using the translocation factor (TF) which is the ratio of metal concentration in the shoots to that in the roots (Yanqun et al., 2005; Yoon et al., 2006; Zou et al., 2011). The equations used to estimate the $\mathrm{BCF}$ and $\mathrm{TF}$ were the following:

$$
B C F=[P b \text { root }] /[P b \text { soil }]
$$

$$
T F=[P b \text { Shoot }] /[P b \text { Root }]
$$

\section{Statistical analysis}

To determine statistical differences between $\mathrm{Pb}$ concentrations in soil, roots and shoots by species and samples period, two-way analysis of variance (ANOVA) and Tukey comparisons were performed with a confidence level of $0.95(P<0.05)$, using SPSS version 23.0. To compare the $\mathrm{Pb}$ level in soil and shoots with the maximum allowable limits (soil: $70 \mathrm{mg} / \mathrm{kg}$; shoot: 10 $\mathrm{mg} / \mathrm{kg}$ ), a single sample " $\mathrm{t}$ " tests was performed.

\section{Results}

\section{Soil composition and $\mathrm{Pb}$ content}


199

200

201

202

203

204

205

206

207

208

209

210

211

212

213

214

215

216

217

218

219

220

221

222

223

224

225

226

227

228

229

230

231

232

233

234

235

236

237

238

239

240

In general, the soil in the study area is classified as aqueous inceptisol. On average it contains $53 \%$ sand, $29 \%$ silt and 18\% clay, which characterizes a sandy loam soil (USDA, 2017), with an organic matter content of $3.9 \%$ (Table 1 ).

No significant differences were found between soil $\mathrm{pH}$ per sampling period and per type of pasture $(P>0.05)$. The $\mathrm{pH}$ range was between 5.03 and 7.73 , indicating that the soils evaluated are weakly acidic to neutral.

Table 1. Average and range of $\mathrm{pH}$, organic matter $(\mathrm{OM})$ and $\mathrm{Pb}$ content in the soil in an area near the polymetallic smelter in the central Andean region of Peru.

\section{Lead concentration in soil, roots and shoots}

The range and average concentration of $\mathrm{Pb}$ in the soil, roots and shoots of high Andean grasses are presented in Table 2 . These concentrations did not vary between pasture types and sampling periods, so the results are shown globally $(\mathrm{n}=40)$. The order of mean $\mathrm{Pb}$ concentrations was soil $>$ root $>$ shoot $(P<0.01)$.

The mean $\mathrm{Pb}$ concentrations in soil and edible part of pastures are considerably higher $(P<$ 0.01 ) than the maximum limits for agricultural soils (MINAM, 2017) and cattle fodder (Boularbah et al., 2006b; Kabata-Pendias and Mukherjee, 2007)

Table 2. Lead concentration in soil, roots and shoots of high Andean grasses $(\mathrm{mg} / \mathrm{kg})$ in an area near the polymetallic smelter in the central Andean region of Peru $(n=40)$.

\section{Lead transfer in the soil-root-shoot system}

The $\mathrm{BCF}$ of $\mathrm{Pb}$ from soil to root was 5.16 times greater than the $\mathrm{TF}$ of $\mathrm{Pb}$ from root to shoot and 7.14 times greater than the $\mathrm{BF}$ of $\mathrm{Pb}$ from soil to shoot $(P<0.01)$, a result that shows that the roots of high Andean pastures produced in a highly contaminated area of the central Andean region bioaccumulate and retain the greatest amount of $\mathrm{Pb}$ from the plant (Table 3).

In the current study, of $100 \%$ of the $\mathrm{Pb}$ of the plant, on average $16 \%$ is found in the shoots and $84 \%$ is concentrated in the root, restricting the translocation of $\mathrm{Pb}$ to the edible part of the grass.

Table 3. Lead transfer factors in the soil-root-shoot system in high Andean pastures in an area near the polymetallic smelter in the central Andean region of Peru.

\section{Discussion}

\section{Physical-chemical characteristics of the soil}

The content of silt, clay and sand in the study area was similar to that reported by Ramirez and Corcuera (2015) in the soils of Paccha (52\% sand, 33\% silt and 15\% clay), being classified as aqueous inceptisol, with a sandy loam texture. Similar results are reported in Mantaro Valley, Apata-Jauja, $80 \mathrm{~km}$ from La Oroya where soils containing 47, 24 and 29\% sand, silt and clay, whose texture is sandy loam - clay loam - sandy loam, with neutral to slightly acidic $\mathrm{pH}$ (Orellana et al., 2019). 
In this study, $\mathrm{OM}$ and $\mathrm{Pb}$ contents in the soil were similar by type of grassland and sampling period $(\mathrm{P}>0.05)$, so the degree of solubility and bioavailability of $\mathrm{Pb}$ for plants would also be similar throughout the year (Lokeshwari \& Chandrappa, 2006) in chronic contamination case.

In the study area the $\mathrm{pH}$ was slightly acidic to neutral and the availability of $\mathrm{Pb}$ would be similar at the different sampling sites where the OM levels were also similar (Table 1).

The results of the study are indicative of the low OM content of Andean soils in central Peru, and due to the high and persistent toxicity of $\mathrm{Pb}$ improvements should be made so that the soil has at least 5\% OM (Enya et al., 2020) recommending fertilization with high Andean cattle manure.

\section{Lead concentration in soil, roots and shoots}

The soils of La Oroya have been contaminated since the smelter began operations in 1922 (Chirinos-Peinado and Castro-Bedriñana, 2020). For 2007 and 2008, in La Oroya and Paccha (study area), an average concentration of $\mathrm{PM}_{2.5}$ particles of 32.4 and $20.3 \mathrm{ug} / \mathrm{m}^{3}$ was reported, values that exceed the Environmental Quality Standard (EQS $=15 \mathrm{ug} / \mathrm{m}^{3}$ ) and for $\mathrm{PM}_{10}$ of 52.3 and $42.4 \mathrm{ug} / \mathrm{m}^{3}$ values similar to the EQS $\left.=50 \mathrm{ug} / \mathrm{m}^{3}\right)$ (MINAM, 2008), which would be deposited in the soil and most likely assimilated by plants and animals, which could affect human health at the end of the food chain (Kryshna \& Mohan, 2016; Li et al, 2017).

As observed in several studies (Peláez-Peláez, Bustamante and Gómez, 2016; Ashraf et al., 2017), $\mathrm{Pb}$ content decreased in the order soil $>$ root $>$ shoot $(P<0.01)$; however, $15 \%$ of the root samples had more $\mathrm{Pb}$ than soil.

Lead concentrations in soil and in shoots are above the maximum permitted levels, $70 \mathrm{mg} / \mathrm{kg}$ for soil and $10 \mathrm{mg} / \mathrm{kg}$ for shoots. Only $14.4 \%$ of root $\mathrm{Pb}$ is translocated to the shoots, so $\mathrm{Pb}$ enrichment in the roots would act as a barrier to heavy metal translocation, limiting its transfer to the aerial part of the grassland, as reported in Trifolium repens and Lolium perenne (Bidar et al, 2009), Panicum maximum, Brachiaria decumbens and Brachiaria brizantha (Nascimento et al. 2014) and in other plants (Akinci, Akinci \& Yilmaz, 2010; Fahr et al., 2013; Amari, Ghnaya, Abdelly, 2017). Barrier mechanisms lead to the accumulation of heavy metals in the cell wall (Sharma \& Dubey, 2005; Samardakiewicz et al., 2012; Emamverdian et al, 2015; O'Lexy et al, 2018).

For most plant species, the majority of absorbed lead (approximately 95\%) is accumulated in the roots, and only a small fraction is translocated to aerial plant parts (Kumar, Smita \& Cumbal, 2017). In this study, from the total $\mathrm{Pb}$ in the plant, $88.7 \%$ was accumulated in the roots and $11.3 \%$ was in the shoots (Table 2).

\section{Lead concentration in the soil}

Soil $\mathrm{Pb}$ levels showed no difference between dry and rainy season $(P>0.05)$, coinciding with the report of Osobamiro \& Adewuyi (2015) on agricultural soils in southwestern Ogun State in Nigeria. Other studies find seasonal differences (Bidar et al., 2009; Yabanli, Yozukmaz and Sel, 2014), which could be due to physicochemical differences in soils (Sharma \& Dubey, 2005). 
280

281

282

283

284

285

286

287

288

289

290

291

292

293

294

295

296

297

298

299

300

301

302

303

304

305

306

307

308

309

310

311

312

313

314

315

316

317

318

In the study, there were also no differences in $\mathrm{Pb}$ content between cultivated and natural grassland soil $(P>0.05)$, as suggested by Sharma \& Dubey (2005).

The current result is well above the mean $\mathrm{Pb}$ content of the world's soils $(25 \mathrm{mg} / \mathrm{kg}$ ) (KabataPendias \& Mukherjee, 2007) and it seems likely that $\mathrm{Pb}$ in the soils of the Peruvian Andes, close to mining-metallurgical activities, is at the upper end on a global scale, as reported in several studies (Salman et al, 2019 WoS; Shi et al, 2019; Osobamiro \& Adewuyi, 2015; Santos-Francés et al, 2017; Castro-Bedriñana, Chirinos-Peinado, Peñaloza-Fernández, 2020).

In Peru, the reference value for average $\mathrm{Pb}$ concentrations in agricultural soil is $70 \mathrm{mg} / \mathrm{kg}$ (MINAM, 2017) and in the present study (Table 2) it was observed that the average $\mathrm{Pb}$ concentration was 3.03 times higher than this maximum limit $(P<0.01)$, with negative implications for South American cattle, sheep and camelids and, consequently, for public and environmental health (Chirinos-Peinado and Castro-Bedriñana, 2020). Similarly, it was 4.25 times higher than the limit for forage cultivation recommended by Kabata-Pendias and Pendias (2001) of $50 \mathrm{mg} \mathrm{Pb} / \mathrm{kg}$ of soil.

Our results are also superior to other international references that indicate a range of 7.5 to $135 \mathrm{mg} / \mathrm{kg}$ for agricultural soils in the United States (Pelaez-Pelaez, Bustamante and Gomez, 2016) and in Auckland (New Zealand) that consider a Pb content between 1.5 and $65 \mathrm{mg} / \mathrm{kg}$ (ARC, 2007; Auckland Council, 2015).

Soil $\mathrm{Pb}$ concentrations of 10-30 mg/kg do not affect plant growth (Mlay \& Mgumia, 2010), concentrations above $30 \mathrm{mg} / \mathrm{kg}$ are considered phytotoxic to plants (Boularbah et al, 2006b; Kabata-Pendias and Pendias, 2001), and in our study the soil has 7.1 times more that the fitotoxic concentration.

Considering a reference $\mathrm{Pb}$ content in the Andean soils of Peru of $44.87 \mathrm{mg} / \mathrm{kg}$, before the beginning of mining-metallurgical activities (Santos-Francés et al., 2017), our findings (212.36 $\mathrm{mg} / \mathrm{kg}$ ) are shocking, and may even have legal significance, since the emissions from miningmetallurgical companies would be altering environmental, animal and human health, and would also be causing damages to the economic systems that affect people exposed to these conditions.

The problem of contaminated soils and the products obtained from them has been neglected in Peru. In the central Andes, for many years the $\mathrm{Pb}$ smelter released dangerous doses of $\mathrm{Pb}$ emissions into the air and soil, which are transferred to the food chain (Hou et al, 2014), recommending that decontamination strategies and monitoring of the impact of soil contamination on crop quality be applied (Wuana \& Okieimen, 2011) and that the mining and metallurgical industry control and reduce heavy metal emissions because they can remain in the environment for 150 to 5000 years (Saxena et al, 1999).

\section{Lead concentration in the root}

The average $\mathrm{Pb}$ content in the roots of the high Andean grassland was $154.65 \pm 52.85 \mathrm{mg} / \mathrm{kg}$ (Table 2). Range (77.04 - $263.61 \mathrm{mg} / \mathrm{kg}$ ) was consistent with other reports (Zou et al., 2011; Pourrut et al., 2011; Emamverdian et al., 2015). 
This high $\mathrm{Pb}$ content would force plants to develop tolerance mechanisms in their root system, which would prevent further uptake and translocation to the edible parts of the plant, reducing its harmful effects (Fahr et al., 2013; Amari, Ghnaya \& Abdelly, 2017; Akinci, Akinci \& Yilmaz, 2010).

These mechanisms depend on the species of the plant (Arshad et al., 2008), the concentration of the metal, the duration of exposure (Pourrut et al., 2011), the intensity of stress, the stage of development and the type of organs and tissues of the plant.

Detoxification mechanisms include selective absorption of metals, excretion, complexation by specific ligands, compartmentalization (Gupta et al., 2010; Jiang \& Liu, 2010; Krzesłowska et al., 2010; Maestri et al., 2010), the formation of calluses between the plasma membrane and the cell wall that acts as a barrier against metals (Samardakiewicz et al., 2012; O'Lexy et al., 2018), $\mathrm{Pb}$ sequestration in vacuole with complex formation, action of uronic acids on the cell wall, synthesis of phytochelatines and oxalates, binding with glutathione and amino acids, formation of mycorrhizae, precipitation with radical exudates, synthesis of osmolites and activation of the antioxidant defense system (Sharma \& Dubey, 2005; Emamverdian et al., 2015) to eliminate reactive oxygen species (Pourrut et al., 2011; Ashraf et al., 2017).

Toxicological bioassays report biochemical and physiological actions from exposures as low as $0.1 \mu \mathrm{M} \mathrm{Pb}$ in spruce (Godbolg \& Kettner, 1991), in corn $10^{-5} \mathrm{M}$ Pb (Obroucheva et al., 1998), or in soils above $10 \mathrm{mg} / \mathrm{kg} \mathrm{Pb}$ (Breckle, 1991). Kozlow (2005) reports critical toxicity levels of 10 and $50 \mathrm{mg} / \mathrm{kg}$ for Pb-sensitive and moderately tolerant species; Krämer (2010) reports a critical level of $0.6-28 \mathrm{mg} / \mathrm{kg}$, and Cheng (2003) reports changes in bean cell division with 1.0 ppm $\mathrm{Pb}$.

In most plants, about $90 \%$ of total $\mathrm{Pb}$ accumulates in the root (Kumar, Smita \& Cumbal, 2017). In the present study, the roots accumulated $88.7 \%$ of $\mathrm{Pb}$ from the plant and $11.3 \% \mathrm{was}$ translocated to the aerial part of the grasses.

\section{Lead concentration in shoots}

The outbreaks had 1.97 times more $\mathrm{Pb}$ than the limit value of $10 \mathrm{mg} / \mathrm{kg}$ for fodder (Boularbah et al., 2006b; Kabata-Pendias \& Mukherjee, 2007); they exceeded more times the suggested values for vegetables, such as $3.0 \mathrm{mg} / \mathrm{kg}$ (Robinson et al., 2008) and $0.3 \mathrm{mg} / \mathrm{kg}$ set by the Codex Alimentarius for livestock feed (ONU/FAO, 2018).

The $\mathrm{Pb}$ content in these pastures is attributed to sustained contamination from miningmetallurgical activity in the central highlands of Peru, which permanently threatens Andean livestock, generating problems at the base of the food chain to the detriment of animal and human health and productivity (Chirinos-Peinado \& Castro-Bedriñana, 2020).

In this study, no differences were evidenced between $\mathrm{Pb}$ concentrations by type of pastures and sampling periods, results that are also reported by Orellana et al. (2019). The average content is higher than reported in some regions of the country and the world; thus, in Mantaro-Jauja-Peru district, in soils with $208 \mathrm{mg} / \mathrm{kg}$ of $\mathrm{Pb}$, the aerial sunflower tissues had less than $15 \mathrm{mg} / \mathrm{kg}$ (Munive et al., 2020). In Apata-Jauja, Lolium x hybridum Hausskn and Medicago sativa soils 
359

360

361

362

363

364

365

366

367

368

369

370

371

372

373

374

375

376

377

378

379

380

381

382

383

384

385

386

387

388

389

390

391

392

393

394

395

396

397

398

had $57.17 \pm 6.29$ and $50.10 \pm 8.99 \mathrm{mg} / \mathrm{kg} \mathrm{Pb}$ and the aerial part of these grasses had $1.17 \pm 0.69$ and $1.62 \pm 0.68 \mathrm{mg} / \mathrm{kg}(P>0.05)$ (Orellana et al., 2019). In Paccha-Yauli-Peru, in soils with $132-284 \mathrm{mg} / \mathrm{kg} \mathrm{Pb}$, the sprouts of natural and cultivated grasses had 19.5 and $20.7 \mathrm{mg} / \mathrm{kg} \mathrm{Pb}$ (Castro-Bedriñana, Chirinos-Peinado \& Peñaloza-Fernández, 2020).

In Magdalena-Colombia, in Brachiaria decumbens, B. humidicola and B. brizantha, cultivated near the oil refinery, in leaves and stems are reported $2.04-3.34$ and $3.16-5.36 \mathrm{mg} / \mathrm{kg}$ $\mathrm{Pb}$ (Peláez-Peláez, Bustamante \& Gómez, 2016). Pb contents between 0.11 and $0.21 \mathrm{mg} / \mathrm{kg}$ are reported in cultivated pastures in New Zealand (Longhurst, Roberts \& Waller, 2004), in those of southern New Zealand 10.6 mg / kg (Martin et al., 2017), in Kjeller-Norway 8.4-9.6 mg / kg (Johnsen \& Aaneby, 2019), in the Netherlands $0.6 \mathrm{mg} / \mathrm{kg}$ (Adamse, Fels-Klerk \& Jong (2017) and in the central mountainous part of the Kakheti-Georgia region 0.02-0.28 mg / kg (Bregvadze et al., 2018).

In Lolium multiflorum Lam. in artificially prepared soils with $60 \mathrm{mg} / \mathrm{kg} \mathrm{Pb}$ and different $\mathrm{pH}$ values and $\mathrm{OM}$ contents, the shoots had between 4.42-10.90 $\mathrm{mg} / \mathrm{kg} \mathrm{Pb}$; the $\mathrm{OM}$ content was inversely related to the $\mathrm{Pb}$ content and the higher the acidic soil, the higher the $\mathrm{Pb}$ content (Kwiatkowska-Malina \& Maciejewska, 2013).

In Trifolium alexandrinum, one of the main forage crops in Punjab-India, $\mathrm{Pb}$ contents between 2.83-9.17 and 2.5-4.33 mg / kg are reported in soils and shoots (Bhatti, Sambyal \& Nagpal, 2016).

On the other hand, the $\mathrm{Pb}$ content of the shoots in this study was lower than that found in more contaminated soils, such as in Recuay-Ancash-Peru (3433 m a.s.1.) in soils near a polymetallic mining concession that has been operating for 70 years, the highest $\mathrm{Pb}$ concentration was in the Juncus bufonius root $(718.44 \mathrm{mg} / \mathrm{kg})$ and in the Pennisetum clandestinum shoot (236.86 mg / kg) (Chang Kee et al., 2018).

In Hualgayoc-Cajamarca-Peru, around a polymetallic mine (soils with 120 to $111,290 \mathrm{mg} / \mathrm{kg}$ $\mathrm{Pb}$ ), the shoots of Plantago orbignyana Steinheil, Lepidium bipinnatifidum Desv., Baccharis latifolia Ruiz \& Pav Pers. and Sonchus oleraceus L. had between 6070-8240, 6300-7240, 2120 3060 and 2180-2900 mg / kg (Bech et al, 2012).

At sites near Indian metallurgical activities, the $\mathrm{Pb}$ in forage was $29.06 \mathrm{mg} / \mathrm{kg}$ (Swarup et al, 2005), while at non-industrialized sites it was $2.08 \mathrm{mg} / \mathrm{kg}$. In contaminated soils in Pakistan, average $\mathrm{Pb}$ concentrations between 36.85 and $60.21 \mathrm{mg} / \mathrm{kg}$ are reported for Trifolium alexandrium, Brassica campestris and Avena sativa grasslands (Iqbal et al., 2015).

In Ibadan-Nigeria, in soils contaminated with Pb-slag, grasses were between 209 and $899 \mathrm{mg}$ / kg (Ogundiran et al., 2012). In Liaoning-China, in soils with $1560 \mathrm{mg} / \mathrm{kg} \mathrm{Pb}$ ) the Pb concentration in Lolium perenne sprouts was $34.38 \mathrm{mg} / \mathrm{kg}$ (Zhang et al., 2017) and in another study in artificially contaminated soils with 500-1500 mg / kg Pb, Lolium perenne sprouts had more than $50 \mathrm{mg} / \mathrm{kg}$ (Zhang et al., 2019).

One aspect to consider is that, although $\mathrm{Pb}$ from the air could enter the plant through the leaves, it has been established that most of it is absorbed from the soil and accumulates in the roots from where it moves to the shoots (Sharma and Dubey, 2005; Kumar, Smita \& Cumbal, 
399

400

401

402

403

404

405

406

407

408

409

410

411

412

413

414

415

416

417

418

419

420

421

422

423

424

425

426

427

428

429

430

431

432

433

434

435

436

437

438

2017; Wu et al., 2020). In field studies evaluating the bioaccumulation and translocation of heavy metals, no reference is made to their possible absorption from the air through the leaves, so little is known about this complex and important issue, which would be influenced by the morphological and histological characteristics of the leaves and the size, load and composition of the particles emitted (Sharma et al., 2020).

\section{Lead transfer in the soil-root-shoot system}

$\mathrm{The} \mathrm{Pb}$ content of the soil is transferred and bioaccumulates in the edible parts of the forage, being a direct route for its incorporation into the food chain, causing damage to soil microorganisms, plants, animals and humans (Tóth et al., 2016; Kryshna and Mohan, 2016; Hou et al., 2014; Chirinos-Peinado and Castro-Bedriñana, 2020).

The bioconcentration factor $(\mathrm{BCF})$ of $\mathrm{Pb}$ from soil to roots was $0.74 \pm 0.26$ (range: 0.31-1.43 $\mathrm{mg} / \mathrm{kg}$ ) (Table 3). The $17.4 \%$ of the pasture samples had a BCF $>$ of 1 , a result that indicates that Andean grasses could be considered moderate accumulators of $\mathrm{Pb}$ (Chang Kee et al., 2018, Zhang et al., 2019; Wu et al, 2020), since their roots absorb and bioconcentrate a large part of the $\mathrm{Pb}$ present in the soil and retain it (Sharma and Dubey, 2005; Bech et al., 2012; Kumar, Smita and Cumbal, 2017; Wu et al., 2020), transferring it to a lesser extent to the aerial part of the plant; however, the grassland shoots evaluated have a high $\mathrm{Pb}$ content for animal feed (ONU/FAO, 2018).

The determination of the bioaccumulation factor (BF) of heavy metals in the sprouts in relation to the total soil content is an appropriate method to quantify the bioavailability of the metals, and also reflects the capacity of the plants to mobilize and capture the heavy metals. $\mathrm{Pb}$ has a lower bioaccumulation factor (BF) than other metals because it is bound to soil colloids and is less bioavailable to the plant (Violante et al., 2010) and in this study its value was lower than the average recorded for spinach, lettuce, carrots, and radishes grown in soils containing $100 \mathrm{mg} / \mathrm{kg}$ $\mathrm{Pb}$ (Intawongse \& Dean, 2008), which would indicate that pastures bioaccumulate less $\mathrm{Pb}$ than vegetables.

The translocation factor $(\mathrm{TF})$ of $\mathrm{Pb}$ from root to shoot of the evaluated grasses ratifies the cumulative action of the root (Kumar, Smita and Cumbal, 2017; Wu et al., 2020) by translocating a low percentage of lead to the shoot.

\section{Implications for central Peru}

The results contribute to the current knowledge about $\mathrm{Pb}$ transfer in the soil-root-plant system in the grasslands of the Andean region, a topic little explored in this part of the world where metallurgical mining activity emits particulate material loaded with lead and other heavy metals since 1922; therefore, it is a critical problem that must be solved.

Our results agree with Du and others (2020) that the main source of heavy metals is the mining and smelting operations.

The data from this study show that agri-food production on $\mathrm{Pb}$-contaminated substrates in areas close to mining-metallurgical activity is a serious public health problem, and if the mining- 
439

440

441

442

443

444

445

446

447

448

449

450

451

452

453

454

455

456

457

458

459

460

461

462

463

464

465

466

467

468

469

470

471

472

473

474

475

476

477

478

479

metallurgical industry does not improve its production processes and if strict environmental adaptation programs are not implemented, the rate of chronic $\mathrm{Pb}$ bioaccumulation could continue with serious effects especially on vulnerable populations (children, pregnant mothers and babies), leading to undesirable economic and social outcomes in exposed populations.

A new Peruvian guideline on the levels of $\mathrm{Pb}$ and other heavy metals in soil, feed, and food could help correct this problem and minimize the adverse effects of contamination.

\section{Conclusions}

This research has revealed that the mining-metallurgical activity developed in central Peru during almost a century has had an impact on the high concentration of $\mathrm{Pb}$ in the upper soil layer and in the natural and cultivated pastures of the central highlands of Peru.

Lead in soil was 3.04 times higher than the maximum limit for agricultural soil and in forage was 1.97 times higher than the limit value for forage, and of the total $\mathrm{Pb}$ content in pastures about $90 \%$ accumulates in the roots.

The study provides comparable information on the content and transfer of $\mathrm{Pb}$ in the soil-rootplant system of pastures used to feed livestock raised in areas close to polymetallic miningmetallurgical activity in the high central Andes of Peru. The study is one of the first in this part of the world, and the conclusions are shocking and could lead to socio-economic problems in exposed populations.

\section{Acknowledgements}

The authors are grateful to engineer Surveyor Cochachi, director of the Yauli-La Oroya Agricultural Agency, for his contact with Peasant Paccha Community. We also thank the editor and reviewers for their valuable suggestions and comments that have improved this scientific article.

\section{References}

Adamse P, Van der Fels-Klerx HJ (Ine), de Jong J. 2017. Cadmium, lead, mercury and arsenic in animal feed and feed materials - trend analysis of monitoring results. Food Additives and Contaminants: Part A. https://doi.org/10.1080/19440049.2017.1300686

Akinci IE, Akinci S, Yilmaz K. 2010. Response of tomato (Solanum lycopersicum L.) to lead toxicity: growth, element uptake, chlorophyll and water content. Afr. J. Agric. Res., 5(6), 416423. https://doi.org/10.5897/AJAR10.016

Alloway B. 2013. Heavy Metals in Soils: Trace Metals and Metalloids in Soils and Their Bioavailability. Environmental Pollution. https://doi.org/10.1007/978-94-007-4470-7

Alvarez-Berríos N, Campos-Cerqueira M, Hernández-Serna A, Amanda Delgado JC, RománDañobeytia F. 2016. Impacts of small-scale gold mining on birds and anurans near the Tambopata Natural Reserve, Peru, assessed using passive acoustic monitoring. Tropical Conservation Science, 9(2), 832-851. https://doi.org/10.1177/194008291600900216 
480

481

482

483

484

485

486

487

488

489

490

491

492

493

494

495

496

497

498

499

500

501

502

503

504

505

506

507

508

509

510

511

512

513

514

515

516

517

518

519

Amari T, Ghnaya T, Abdelly C. 2017. Nickel, Cadmium and Lead phytotoxicity and potential of halophytic plants in heavy metal extraction. South African Journal of Botany, 111(1), 99-110. https://doi.org/10.1016/j.sajb.2017.03.011

AOAC. 1990. AOAC - Official Method 975.03. Metals in plants: Atomic Absorption Spectrophotometric Method. Association of Official Analytical Chemists. https://law.resource.org/pub/us/cfr/ibr/002/aoac.methods.1.1990.pdf

ARC. 2007. Health effects of air pollution. Auckland Regional Council. http:/www.arc.govt.nz/albany/fms/main/Documents/Environment/Pollution/airfacts5.pdf

Arshad M, Silvestre J, Pinelli E, Kallerhoff J, Kaemmerer M, Tarigo A, Shahid M, Guiresse M, Pradere P, Dumat C. 2008. A field study of lead phytoextraction by various scented Pelargonium cultivars. Chemosphere 71(11):2187-2192. https://doi.org/10.1016/j.chemosphere.2008.02.013

Ashraf U, Kanu AS, Deng Q, Mo Z, Pan S, Tian H, Tang X. 2017. Lead (Pb) Toxicity; PhysioBiochemical Mechanisms, Grain Yield, Quality, and Pb Distribution Proportions in Scented Rice. Frontiers in Plant Science, 8, 259. https://doi.org/10.3389/fpls.2017.00259

ATSDR. 2007. Priority List of Hazardous Substances. Agency for Toxic Substances and Diseases Registry. Available at: http://www.atsdr.cdc.gov/.

Auckland Council. 2015. State of environment report 2015. The health of Auckland's natural environment in 2015. https://www.aucklandcouncil.govt.nz/environment/state-of-aucklandresearch-report-cards/Documents/stateofenvironmentreport2015.pdf

Bhatti SS, Sambyal V, Nagpal AK. 2016. Heavy metals bioaccumulation in Berseem (Trifolium alexandrinum) cultivated in areas under intensive agriculture, Punjab, India. SpringerPlus (2016) 5:173. https://doi.org/10.1186/s40064-016-1777-5

Bech J, Duran P, Roca N, Poma W, Sánchez I, Barceló J, Boluda R, Roca-Pérez L, Poschenrieder C. 2012. Shoot accumulation of several trace elements in native plant species from contaminated soils in the Peruvian Andes. Journal of Geochemical Exploration. 113, 106-111. https://doi.org/10.1016/j.gexplo.2011.04.007

Bidar G, Pruvot C, Garçon G, Verdin A, Shirali P, Douay F. 2009. Seasonal and annual variations of metal uptake, bioaccumulation, and toxicity in Trifolium repens and Lolium perenne growing in a heavy metal-contaminated field. Environ Sci Pollut Res., 16(1), 42-53. https://doi.org/10.1007/s11356-008-0021-4

Blacksmith Institute. 2007. The World's Worts Polluted Places: The Top Ten of The Dirty Thirty. A Project of the Blacksmith Institute. New York City. http://www.bpb.de/files/P22JU5.pdf

Boularbah A, Schwartz C, Bitton G, Morel JL. 2006a. Heavy metal contamination from mining sites in South Morocco: 1. Use of a biotest to assess metal toxicity of tailings and soils. Chemosphere, 63(5), 802-810. https://doi.org/10.1016/j.chemosphere.2005.07.079.

Boularbah A, Schwart C, Bitton G, Aboudrar W, Ouhammou A, Morel JL. 2006b. Heavy metal contamination from mining sites in South Morocco: 2. Assessment of metal accumulation and toxicity in plants. Chemosphere, 63(5),811-817. https://doi.org/10.1016/j.chemosphere.2005.07.076 
520 Breckle SW. 1991. Growth under stress. Heavy metals. In: Waisel Y, Eshel A, Kafkafi U (eds),

521

522

523

524

525

526

527

528

529

530

531

532

533

534

535

536

537

538

539

540

541

542

543

544

545

546

547

548

549

550

551

552

553

554

555

556

557

558

559

Plant Roots: The Hidden Half, pp. 351-373. Marcel Dekker Inc., New York, USA.

Bregvadze Z, Enukidzeb L, Chelidzeb T, Didebulidze A, Loladzeb T, Chankashvili M. 2018. Investigation of ecological purity of village pastures in Kakheti Region based on the analysis of toxic metals in grass. Annals of Agrarian Science. https://doi.org/10.1016/j.aasci.2018.04.014

Castro Bedriñana J, Chirinos Peinado D, Ríos Ríos E. 2016. Lead content and placental weight and its association with gestational age, weight, length and hemoglobin in newborns of metallurgical region - Peru. Revista de Toxicologia, 33(2), 88-92.

Castro-Bedriñana J, Chirinos-Peinado D, Peñaloza-Fernández R. 2020. Lead Bioaccumulation in Root and Aerial Part of Natural and Cultivated Pastures in Highly Contaminated. Advances in Science, Technology and Engineering Systems Journal Vol. 5, No. 2, 126-132. https://dx.doi.org/10.25046/aj050216

Caussy D, Gochfeld M, Gurzau E, Neagu C, Ruedel H. 2003. Lessons from case studies of metals: investigation exposure, bioavailability, and risk. Ecotoxicol Environ Safe, 56(1), 45-51. https://doi,org/10.1016/s0147-6513(03)00049-6

Chang Kee J, Gonzales MJ, Ponce O, Ramírez L, León V, Torres A, Corpus M, Loayza-Muro, R. 2018. Accumulation of heavy metals in native Andean plants: potential tools for soil phytoremediation in Ancash (Peru). Environ Sci Pollut Res. 25(34), 33957-33966. https://doi.org/10.1007/s11356-018-3325-Z

Chen S, Wang M, Li S, Zhao Z, Wen-di. 2018. Overview on current criteria for heavy metals and its hint for the revision of soil environmental quality standards in China. Journal of Integrative Agriculture, 17(4), 765-774. https://doi.org/10.1016/s2095-3119(17)61892-6

Cheng, S. 2003. Effects of Heavy metals on plants and resistance mechanisms. Environmental Science and Pollution Research, 10(4), 256-264. https://doi.org/10.1065/espr2002.11.141.2

Chirinos-Peinado D, Castro-Bedriñana J. 2020. Lead and cadmium blood levels and transfer to milk in cattle reared in a mining area. Heliyon 6 (2020) e03579. https://doi.org/10.1016/j.heliyon.2020.e03579

Du B, Zhou J, Lu B, Zhang C, Li D, Zhou J, Jiao S, Zhao K, Zhang H. 2020. Environmental and human health risks from cadmium exposure near an active lead-zinc mine and a copper smelter, China. Science of The Total Environment, 720, 137585. https://doi.org/10.1016/j.scitotenv.2020.137585

Emamverdian A, Ding Y, Mokhberdoran F, Xie Y. 2015. Estrés por metales pesados y algunos mecanismos de respuesta de defensa vegetal. The Scientific World Journal, 2015, 1-18. $\underline{\text { https://doi,org/10.1155/2015/756120 }}$

Enya O, Heaney N, Iniama G, Lin C. 2020. Effects of heavy metals on organic matter decomposition in inundated soils: Microcosm experiment and field examination. Science of The Total Environment, 138223. https://doi.org/10.1016/j.scitotenv.2020.138223

Fahr M, Laplaze L, Bendaou N, Hocher V, Mzibri ME, Bogusz D, Smouni A. 2013. Effect of lead on root growth. Front. Plant Sci., 6(4),175-83. https://doi.org/10.3389/fpls.2013.00175

Peer] reviewing PDF | (2020:05:49350:2:3:NEW 24 Nov 2020) 
560

561

562

563

564

565

566

567

568

569

570

571

572

573

574

575

576

577

578

579

580

581

582

583

584

585

586

587

588

589

590

591

592

593

594

595

596

597

Gessesse TA, Khamzina A. 2018. How reliable is the Walkley-Black method for analyzing carbonpoor, semi-arid soils in Ethiopia? Journal of Arid Environments, 153, 98-101. https://doi.org/10.1016/j.jaridenv.2018.01.008

Goldbold DL, Kettner C. 1991. Lead influences root growth and mineral nutrition of Picea abies seedlings. J. Plant Physiol. 139(1), 95-99. https://doi.org/10.1016/s0176-1617(11)80172-0

Gupta D, Huang H, Yang X, Razafindrabe B, Inouhe M. 2010. The detoxification of lead in Sedum alfredii $\mathrm{H}$. is not related to phytochelatins but the glutathione. J Hazard Mater. 177(1-3):437444. https://doi.org/10.1016/j.jhazmat.2009.12.052

Hou Q, Yang Z, Ji J, Yu T, Chen G, Li J, Xia X, Zhang M, Yuan X. 2014. Annual net input fluxes of heavy metals of the agro-ecosystem in the Yangtze River delta, China. Journal of Geochemical Exploration, 139, 68-84. https://doi.org/10.1016/j.gexplo.2013.08.007

Hu W, Huang B, Tian K, Holm PE, Zhang Y. 2017. Heavy metals in intensive greenhouse vegetable production systems along Yellow Sea of China: Levels, transfer and health risk. Chemosphere. Jan; 167:82-90. http://dx.doi.org/10.1016/j.chemosphere.2016.09.122

Intawongse M, Dean JR. 2008. Use of the physiologically-based extraction test to assess the oral bioaccessibility of metals in vegetable plants grown in contaminated soil. Environ. Pollut. 152, 60-72. https://doi.org/10.1016/j.envpol.2007.05.022

Iqbal Z, Ahmad K, Aisha N, Mustafa I, Ibrahim M, Fardous A, Gondal S, Hussain A, Arshad F, Rasul I, Yousaf M, Fawad A, Sher M, Hussain A, Ahmad H, Rashid U. 2015. Heavy Metals Concentration in Soil-Plant-Animal Continuum under Semi-Arid Conditions of Punjab, Pakistan. Pakistan J. Zool. 47(2), 377-382.

Jiang W, Liu D. 2010. Pb-induced cellular defense system in the root meristematic cells of Allium sativum L. BMC Plant Biol 10:40-40

Johnsen IV, Aaneby J. 2019. Soil intake in ruminants grazing on heavy-metal contaminated shooting ranges. Science of The Total Environment, 687, 4149. https://doi.org/10.1016/j.scitotenv.2019.06.086

Kabata-Pendias A, Mukherjee AB. 2007. Plants. In: Trace Elements from Soil to Human. Springer Berlin Heidelberg. New York, p 550. https://doi.org/10.1007/978-3-540-32714-1_6

Kabata-Pendias A, Pendias H. 2001. Trace Elements in Soils and Plants. 3rd ed.; New York. CRC Press Inc.: Boca Raton, USA. http://base.dnsgb.com.ua/files/book/Agriculture/Soil/TraceElements-in-Soils-and-Plants.pdf

Kong X. 2014. China must protect high-quality arable land. Nature 506, 7. https://doi.org/10.1038/506007a

Kozlow MV. 2005. Pollution resistance of mountain birch, Betula pubescens subsp. czerepanovii, near the copper-nickel smelter: natural selection or phenotypic acclimation? Chemosphere 59(2), 189-197. https://doi.org/10.1016/j.chemosphere.2004.11.010

Krämer U. 2010. Metal hyperaccumulation in plants. Annu Rev Plant Biol. 61, 517-534. https://doi.org/10.1146/annurev-arplant-042809-112156 
598

599

600

601

602

603

604

605

606

607

608

609

610

611

612

613

614

615

616

617

618

619

620

621

622

623

624

625

626

627

628

629

630

631

632

633

634

635

636

Kryshna AK, Mohan KR. 2016. Distribution, correlation, ecological and health risk assessment of heavy metal contamination in surface soils around an industrial area, Hyderabad, India. Environ Earth Sci, vol.75 no.5 pp. 411. https://doi.org/10.1007/s12665-015-5151-7

Krzesłowska M, Lenartowska M, Samardakiewicz S, Bilski H, Wo'zny A (2010) Lead deposited in the cell wall of Funaria hygrometrica protonemata is not stable-a remobilization can occur. Environ Pollut. 158(1):325-338. https://doi.org/10.1016/j.envpol.2009.06.035

Kumar B, Smita K, Cumbal L. 2017. Plant mediated detoxification of mercury and lead. Arabian Journal of Chemistry, 10, S2335-S2342. https://doi.org/10.1016/j.arabjc.2013.08.010

Kwiatkowska-Malina J, Maciejewska A. 2013. Uptake of heavy metals by darnel multifloral (Lolium multiflorum Lam.) at diverse soil reaction and organic matter content. Soil Science Annual, 64(1), 19-23.https://doi.org/10.2478/ssa-2013-0004

Li F, Zhang J, Huang J, Huang D, Yang J, Song Y, Zeng G. 2016. Heavy metals in road dust from Xiandao District, Changsha City, China: characteristics, health risk assessment, and integrated source identification. Environ Sci Pollut Res Int. 23(13):13100-13. https://doi.org/10.1007/s11356-016-6458-y

Li F, Zhang J, Jiang W, Liu C, Zhang Z, Zhang C, Zeng G. 2017. Spatial health risk assessment and hierarchical risk management for mercury in soils from a typical contaminated site, China. Environ Geochem Health. 39 (4): 923-934. https://doi.org/10.1007/s10653-016-9864-7

Li Y, MCcrory DF, Powell JM, Saam H, Jackson-Smith D. 2005. A survey of selected heavy metal concentration in Wisconsin dairy feeds. J. Dairy Sci. 88(8), 2911-22. https://doi.org/10.3168/jds.S0022-0302(05)72972-6

Lokeshwari H, Chandrappa GT. 2006. Impact of heavy metal contamination of Bellandur Lake on soil and cultivated vegetation. Current Science, 91(5), 622-627. https://www.jstor.org/stable/24094365

Longhurst RD, Roberts AHC, Waller JE. 2004. Concentrations of arsenic, cadmium, copper, lead, and zinc in New Zealand pastoral topsoils and herbage. New Zeal. J. Agr. Res. 47 (1), 23-32. https://doi.org/10.1080/00288233.2004.9513567

Maestri E, Marmiroli M, Visioli G, Marmiroli N. 2010. Metal tolerance and hyperaccumulation: costs and trade-offs between traits and environment. Environ Exp Bot 68(1):1-13. https://doi.org/10.1016/j.envexpbot.2009.10.011

Martin AP, Turnbull RE, Rissmann CW, Rieger P. 2017. Heavy metal and metalloid concentrations in soils under pasture of southern New Zealand. Geoderma Regional, 11, 1827. https://doi.org/10.1016/j.geodrs.2017.08.005

MINAM. 2008. Decreto Supremo No 003-2008-MINAM. Aprueban los estándares nacionales de calidad ambiental para aire. Ministerio del Ambiente. https://sinia.minam.gob.pe/normas/estandares-nacionales-calidad-ambiental-aire.

MINAM. 2017. DS N011-2017-MINAM. Aprueban Estándares de Calidad Ambiental (ECA) para Suelo. Perú: El Peruano. https://sinia.minam.gob.pe/normas/aprueban-estandares-calidadambiental-eca-suelo-0 
637

638

639

640

641

642

643

644

645

646

647

648

649

650

651

652

653

654

655

656

657

658

659

660

661

662

663

664

665

666

667

668

669

670

671

672

673

674

675

676

Mlay PS, Mgumia Y. 2010. Levels of lead and copper in plasma of dairy cows, pastures, soil and water from selected areas of Morogoro suburbs, Tanzania. Livestock Research for Rural Development. 20(4), paper 60. http://www.1rrd.org/lrrd20/4/mlay20060.htm

Munive R, Gamarra G, Munive Y, Puertas F, Valdiviezo L, Cabello R. 2020. Lead and cadmium uptake by sunflower from contaminated soil and remediated with organic amendments in the form of compost and vermicompost. Scientia Agropecuaria, 11(2), 177-186. https://doi.org/10.17268/sci.agropecu.2020.02.04

Nascimento SS, Silva E, Alleoni LR, Grazziotti P, Fonseca F, Nardis B. 2014. Availability and accumulation of lead for forage grasses in contaminated soil. Journal of Soil Science and Plant Nutrition, 14(4), 783-802. http://dx.doi.org/10.4067/S0718-95162014005000063

Obroucheva NV, Bystrova EI, Ivanov VB, Anupova OV, Seregin IV. 1998. Root growth responses to lead in young maize seedlings. Plant Soil 200:55-61. https://doi.org/10.1023/A:1004204605833

Ogundiran MB, Ogundele DT, Afolayan P, Osibanjo O. 2012. Heavy Metals Levels in Forage Grasses, Leachate and Lactating Cows Reared around Lead Slag Dumpsites in Nigeria. Int. J. Environ. Res., 6(3):695-702. https://doi.org/10.22059/IJER.2012.540

ONU/FAO. 2018. General standard for contaminants and toxins in food and feed CXS 193-1995 (Adopted in 1995, amended in 2017). Codex Alimentarius Commission, FAO/WHO, Rome. 2018.

O'Lexy R, Kasai K, Clark N, Fujiwara T, Sozzani R, Gallagher KL. Exposure to heavy metal stress triggers changes in plasmodesmatal permeability via deposition and breakdown of callose. $\mathrm{J}$ Exp Bot. 2018;69(15):3715-3728. https://doi.org/10.1093/jxb/ery171

Orellana E, Custodio M, Bastos M, Cuadrado W. 2019. Lead in Agricultural Soils and Cultivated Pastures Irrigated with River Water Contaminated by Mining Activity, 20(8), 238-244. https://doi.org/10.12911/22998993/111715

Osobamiro MT, Adewuyi GO. 2015. Levels of Heavy Metals in the Soil: Effects of Season, Agronomic Practice and Soil Geology. Journal of Agricultural Chemistry and Environment, 4, 109-117. http://dx.doi.org/10.4236/jacen.2015.44012

Peláez-Peláez MJ, Bustamante CJ, Gómez LE. 2016. Presencia de cadmio y plomo en suelos y su bioacumulación en tejidos vegetales en especies de Brachiaria en Magdalena medio colombiano. Revista Luna Azul. 43:82-101. https://doi.otg/10.17151/luaz.2016.43.5

Pourrut B, Shahid M, Dumat C, Winterton P, Pinelli E. 2011. Lead Uptake, Toxicity, and Detoxification in Plants. Reviews of Environmental Contamination and Toxicology. 213, 113136. https://doi.org/10.1007/978-1-4419-9860-6 4

Ramírez J, Corcuera V. 2015. Diagnóstico de la calidad del suelo del área de influencia del Complejo Metalúrgico La Oroya. Universidad Nacional de Trujillo. http://dspace.unitru.edu.pe/handle/UNITRU/3269

Ramsumair A, Mlambo V, Lallo C. 2014. Effect of drying method on the chemical composition of leaves from four tropical tree species. Trop. Agric. (Trinidad) 91(3), 179-186.

https://www.researchgate.net/publication/264545539 
677 Robinson BH, Bischofberger S, Stoll A, Schroer D, Furrer G, Roulier S, Gruenwald A, Attinger, 678 W, Schulin R. 2008. Plant uptake of trace elements on a Swiss military shooting range: Uptake 679 pathways and land management implications. Environmental Pollution, 153(3), 668680 676. https://doi.org/10.1016/j.envpol.2007.08.034

681 Salman SA, Zeid SAM, Selem EM, Abdel-Hafiz A. 2019. Soil characterization and heavy metal 682 pollution assessment in Orabi farms, El Obour, Egypt. Bull Natl Res Cent. 43:42-55. 683 https://doi.org/10.1186/s42269-019-0082-1.

684 Samardakiewicz S, Krzesłowska M, Bilski H, Bartosiewicz R, Woźny A. 2012. Is callose a barrier 685

686

687

688

689

690

691

692

693

694

695

696

697

698

699

700

701

702

703

704

705

706

707

708

709

710

711

712

713

714

715

716 for lead ions entering Lemna minor L. root cells?. Protoplasma. 249(2):347-51. https://dio.org/10.1007/s00709-011-0285-2

Santos-Francés F, Martínez-Graña A, Alonso P, García A. 2017. Geochemical Background and Baseline Values Determination and Spatial Distribution of Heavy Metal Pollution in Soils of the Andes Mountain Range (Cajamarca-Huancavelica, Peru). Int. J. Environ. Res. Public Health. 14, 859-881. https://doi.org/10.3390/ijerph14080859.

Saxena PK, KrishnaRaj S, Dan T, Perras MR, Vettakkorumakankav NN. 1999. Phytoremediation of Heavy Metal Contaminated and Polluted Soils. In: Heavy Metal Stress in Plants. Springer, Berlin, Heidelberg. https://doi.org/10.1007/978-3-662-07745-0_14

Sharma P, Dubey RS. 2005. Lead toxicity in plants. Braz J Plant Physiol. 17(1):35-52. http://dx.doi.org/10.1590/s1677-04202005000100004

Sharma P, Yadav P, Ghosh C, Singh B. 2020. Heavy metal capture from the suspended particulate matter by Morus alba and evidence of foliar uptake and translocation of PM associated zinc using radiotracer $\quad\left({ }^{65} \mathrm{Zn}\right)$ Chemosphere, $254,126863$. https://doi.org/10.1016/j.chemosphere.2020.126863

Shi T, Ma J, Zhang Y, Liu C, Hu Y, Gong Y, Wu X, Ju T, Hou H, Shao L. 2019. Status of lead accumulation in agricultural soils across China (1979-2016). Environment International, 129, 35-41. https://doi.org/10.1016/j.envint.2019.05.025.

Swarup D, Patra RC, Naresh R, Kumar P, Shekhar P. 2005. Blood lead levels in lactating cows reared around polluted localities; transfer of lead into milk. Sci. Total Environ. 347(1-3), 106110. https://doi.org/10.1016/j.scitotenv.2004.12.055

Tóth G, Hermann T, Da Silva MR, Montanarella L. 2016. Heavy metals in agricultural soils of the European Union with implications for food safety. Environment International, 88, 299-309. https://doi.org/10.1016/j.envint.2015.12.017

Tóth G, Jones A, Montanarella L. 2013. The LUCAS topsoil database and derived information on the regional variability of cropland topsoil properties in the European Union. Environmental Monitoring and Assessment, 185(9), 7409-7425. https://doi.org/10.1007/s10661-013-3109-3

USDA. 2017. Soil Survey Manual. Soil Science Division Staff. United States Department of Agriculture. Agriculture Handbook Nº18, Pág. 199, 202.

USEPA. 1996. United States Environmental Protection Agency, Method 3050B. Acid digestion of sediments, sludges, and soils; United States Environmental Protection Agency: United States. 
717

718

719

720

721

722

723

724

725

726

727

728

729

730

731

732

733

734

735

736

737

738

739

740

741

742

743

744

745

Violante A, Cozzolino V, Perelomov L, Caporale AG, Pigna M. 2010. Mobility and bioavailability of heavy metals and metalloids in soil environments. J. Soil. Sci. Plant Nutr. 10, 268-292. http://dx.doi.org/10.4067/S0718-95162010000100005

Wu J, Wang G, Vijver MG, Bosker T, Peijnenburg WJ. 2020. Foliar versus root exposure of AgNPs to lettuce: Phytotoxicity, antioxidant responses and internal translocation. Environmental Pollution, 114117. https://doi.org/10.1016/j.envpol.2020.114117.

Wuana RA, Okieimen FE. 2011. Heavy Metals in Contaminated Soils: A Review of Sources, Chemistry, Risks and Best Available Strategies for Remediation. ISRN Ecology, 2011, 1-20. https://doi.org/10.5402/2011/402647

Yabanli M, Yozukmaz A, Sel F. 2014. Heavy metal accumulation in the leaves, stem and root of the invasive submerged macrophyte Myriophyllum spicatum L. (Haloragaceae): an example of Kadin Creek (Mugla, Turkey). Braz. arch. biol. technol. 57(3), 434-440. https://doi.org/10.1590/S1516-8913201401962.

Yanqun Z, Yuan L, Jianjun C, Haiyan C, Li Q, Schvartz C. 2005. Hyperaccumulation of Pb, Zn and $\mathrm{Cd}$ in herbaceous grown on lead-zinc mining area in Yunnan, China. Environment International, 31(5), 755-762. https://doi.org/10.1016/j.envint.2005.02.004

Yoon J, Cao X, Zhou Q, Ma LQ. 2006. Accumulation of $\mathrm{Pb}, \mathrm{Cu}$, and $\mathrm{Zn}$ in native plants growing on a contaminated Florida site. Sci Total Environ 368:456-464. https://doi.org/10.1016/j.scitotenv.2006.016.

Zhang W, Yang J, Li Z, Zhou D, Dang F. 2017. Assessment of the availability of As and Pb in soils after in situ stabilization. Environ Sci Pollut Res, 24(29), 23153-23160. https://doi.org/10.1007/s11356-017-9877-5

Zhang Y, Li F, Xu W. Ren J, Chen S, Shen K, Long Z. 2019. Enhanced phytoextraction Cocontaminated soil with $\mathrm{Cd}$ and $\mathrm{Pb}$ by ryegrass (Lolium perenne L.). Bull Environ Contam Toxicol. 103(1), 147-154. https://doi.org/10.1007/s00128-019-02661-7

Zou T, Li T, Zhang X, Yu H, Huang H. 2011. Lead accumulation and phytostabilization potential of dominant plant species growing in a lead-zinc mine tailing. Environmental Earth Sciences, 65(3), 621-630. https://doi.org/10.1007/s12665-011-1109-6 


\section{Table $\mathbf{1}$ (on next page)}

Average and range of $\mathrm{pH}$, organic matter (OM) and $\mathrm{Pb}$ content in the soil in an area near the polymetallic smelter in the central Andean region of Peru

There are no statistical differences between $\mathrm{pH}, \mathrm{MO}$ and $\mathrm{Pb}$ average values per period $(P>$ $0.05)$ 
1

2 Table 1. Average and range of $\mathrm{pH}$, organic matter $(\mathrm{OM})$ and $\mathrm{Pb}$ content in the soil in an area 3 near the polymetallic smelter in the central Andean region of Peru.

4

\begin{tabular}{lccc}
\hline Period & $\mathbf{p H}$ & $\mathbf{O M ~ ( \% )}$ & $\mathbf{P b} \mathbf{( m g} / \mathbf{k g})$ \\
\hline Dry & $6.34[5.03-7.47]$ & $3.89[3.15-4.57]$ & $206.91[125.18-269.93]$ \\
Rain & $6.38[5.08-7.73]$ & $3.93[3.11-4.53]$ & $217.81[131.76-284.13]$ \\
Average & $6.36[5.03-7.73]$ & $3.91[3.11-4.57]$ & $212.36[125.18-284.13]$ \\
\hline
\end{tabular}

5

6 There are no statistical differences between $\mathrm{pH}, \mathrm{MO}$ and $\mathrm{Pb}$ average values per period $(P>0.05)$ 7 


\section{Table 2 (on next page)}

Lead concentration in soil, roots and shoots of high Andean pastures ( $\mathrm{mg} / \mathrm{kg}$ ) in an area near the polymetallic smelter in the central Andean region of Peru $(n=40)$

a, b, c Average Pb contents: soil $>$ root $>$ shoot, vary statistically $(P<0.01)$ 
1

2 Table 2. Lead concentration in soil, roots and shoots of high Andean pastures $(\mathrm{mg} / \mathrm{kg})$ in an area 3 near the polymetallic smelter in the central Andean region of Peru $(n=40)$.

4

\begin{tabular}{lcccccc}
\hline & & & \multicolumn{2}{c}{$95 \%$ Confidence Interval } & & \\
& Average & S. D & Lower limit & Upper limit & Minimum & Maximum \\
\hline Soil & $212.36 \mathrm{a}$ & 38.40 & 200.08 & 224.64 & 125.18 & 284.13 \\
Root & $154.65 \mathrm{~b}$ & 52.85 & 137.75 & 171.56 & 77.04 & 263.61 \\
Shoot & $19.71 \mathrm{c}$ & 2.80 & 18.81 & 20.60 & 13.83 & 23.88 \\
\hline
\end{tabular}

5

6 a, b, c Average $\mathrm{Pb}$ contents: soil $>$ root $>$ shoot, vary statistically $(P<0.01)$ 


\section{Table 3(on next page)}

Lead transfer factors in the soil-root-shoot system in high Andean pastures in an area near the polymetallic smelter in the central Andean region of Peru

a, b: BCF, TF and BF averages whit different letters vary statistically $(P<0.01)$ 
1 Table 3. Lead transfer factors in the soil-root-shoot system in high Andean pastures in an area near 2 the polymetallic smelter in the central Andean region of Peru.

3

\begin{tabular}{ccccccc}
\hline \multirow{2}{*}{ Lead transfer } & Average & S. D & \multicolumn{2}{c}{$95 \%$ Confidence interval } & \multirow{2}{*}{ Minimum } & \multirow{2}{*}{ Maximum } \\
\cline { 4 - 5 } & & & Lower limit & Upper limit & & \\
\hline BCF Soil-Root & $0.743 \mathrm{a}$ & 0.261 & 0.659 & 0.827 & 0.31 & 1.43 \\
TF Root-Shoot & $0.144 \mathrm{~b}$ & 0.057 & 0.126 & 0.162 & 0.06 & 0.29 \\
BF Soil-Shoot & $0.096 \mathrm{~b}$ & 0.025 & 0.088 & 0.104 & 0.06 & 0.18 \\
\hline
\end{tabular}

4

5 a, b, BCF, TF and BF averages whit different letters vary statistically $(P<0.01)$.

6 
Figure 1

Partial map of La Oroya-Peru, research area (3900-4500 m. a.s.I.)

La imagen superior muestra el camino desde el complejo minero-metalúrgico de La Oroya. La imagen inferior muestra el sitio de estudio y la distribución de los puntos de muestreo ( $1 \mathrm{~m}^{2} /$ muestra). Fuente: Elaboración propia. 


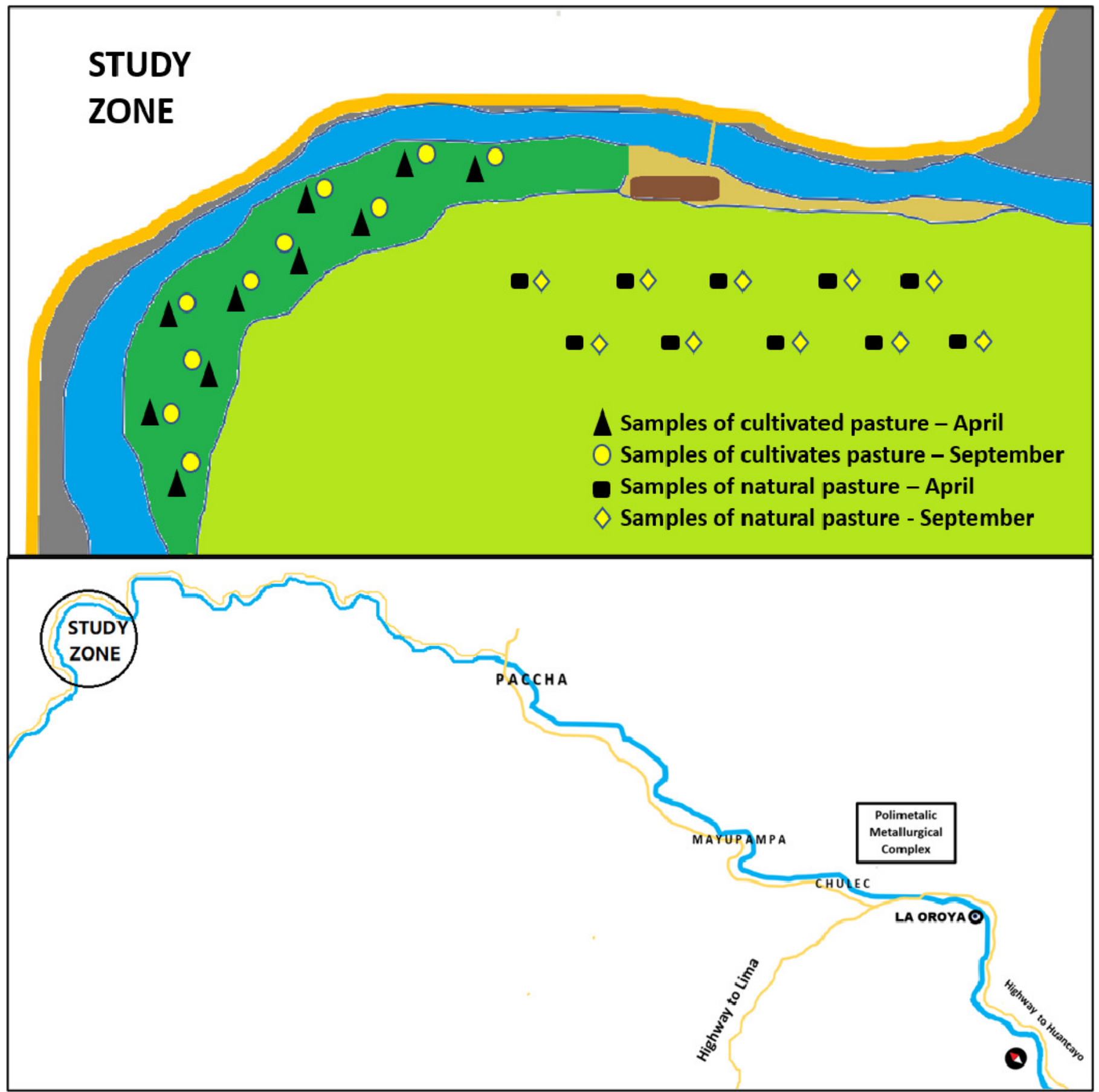

